\title{
Effect of dams' parity and age on daughters' milk yield in Norwegian Red cows
}

\author{
K. S. Storli, ${ }^{, 1}$ B. Heringstad, ${ }^{*} \dagger$ and R. Salte ${ }^{*}$ \\ *Department of Animal and Aquacultural Sciences, Norwegian University of Life Sciences, PO Box 5003, NO-1432 Ås, Norway \\ †Geno Breeding and Al Association, PO Box 5003, NO-1432 Ås, Norway
}

\begin{abstract}
The effect of age and parity of dams on their daughters' milk yield is not well known. Lactation data from 276,000 cows were extracted from the Norwegian Dairy Herd Recording System and analyzed using a linear animal model to estimate effects of parity and age within parity of dam. The 305-d milk yield of daughters decreased as parity of dam increased. Daughters of first-parity dams produced $149 \mathrm{~kg}$ more milk than did daughters of seventh-parity dams. We also observed an effect of age of dam within parity on 305-d milk yield of daughters in first lactation. Dams that were young at first calving gave birth to daughters with a higher milk yield compared with older dams within the same parity. The effect of age within parity of dam was highest for second-parity dams. Extensive use of heifers would have a systematic effect, and age and parity of dam should be included in the model when planning a future strategy.
\end{abstract}

Key words: heifer, dam age, dam parity, milk yield

\section{INTRODUCTION}

To obtain enough heifers for a project aimed to develop the best feeding strategy for a replacement heifer management system for Norwegian Red cows, a major part of the test animals had to be daughters of heifers. This raised the question of whether extensive use of heifers as dams could have a systematic effect on daughters' milk yield. To date, only a few studies have addressed effects of age and parity of dam on milk production of their daughters. Banos et al. (2007) reported that younger first-parity dams gave daughters with higher milk yield than did older first-parity dams. The same was observed for daughters of second-parity dams. Similarly, Fuerst-Waltl et al. (2004) found that ECM yield of daughters decreased with increasing age

Received February 20, 2014.

Accepted June 22, 2014.

${ }^{1}$ Corresponding author: kristin.sivertsen.storli@nmbu.no of dam in Austrian dual-purpose Simmental, whereas Berry et al. (2008) found a negative effect of high milk yield in dams on daughters' milk yield in their first and second lactations. On the other hand, Banos et al. (2007) could not detect any significant effects of maternal milk yield on daughters' milk yield in first lactation.

Available information on the effects of age and parity of dams on the performance of their daughters was unclear. The aim of this study was, therefore, to investigate whether parity of dam and age within parity of dam affect daughters' milk yield in the Norwegian Red breed.

\section{MATERIALS AND METHODS}

\section{Data}

Data were extracted from the Norwegian Dairy Herd Recording System (Ås, Norway) and the final data set included information on 275,707 first-lactation Norwegian Red cows born from 2001 to 2011. Only records for which both sire of daughter and sire of dam were Norwegian Red AI sires were included. Daughters had to be between 18 and 36 mo old at first calving. Twin births were excluded. Only daughters that had completed $305 \mathrm{~d}$ of the first lactation were used. Information from the second lactation for the same daughters ( $\mathrm{n}=145,356)$, using the same editing criteria, was also included. The daughter had to be older than 32 mo at second calving, and age at calving of dam had to be within defined intervals (Table 1). Descriptive statistics of the analyzed data are given in Table 2 .

In total, $38.8 \%$ of first-lactation daughters had firstparity dams, and $27.1 \%$ had second-parity dams. Likewise, $38.3 \%$ of dams of second-lactation daughters were first-parity dams, and $26.9 \%$ were second-parity dams. The distribution of parity of dams is given in Figure 1. About $20 \%$ of the dams were fourth- to seventh-parity dams; parities $>7$ were excluded. The phenotypic trend for average 305-d milk yield of daughters calving from 2003 to 2012 by parity of dam is shown in Figure 2. Average 305-d milk yield increased with time for 
Table 1. Estimated effects (BLUE = best linear unbiased estimator) with standard error of age $\times$ parity of dam, expressed as deviation from dams older than 95 mo in parity 7, on 305-d milk yield $(\mathrm{kg})$ of daughters in first and second lactation

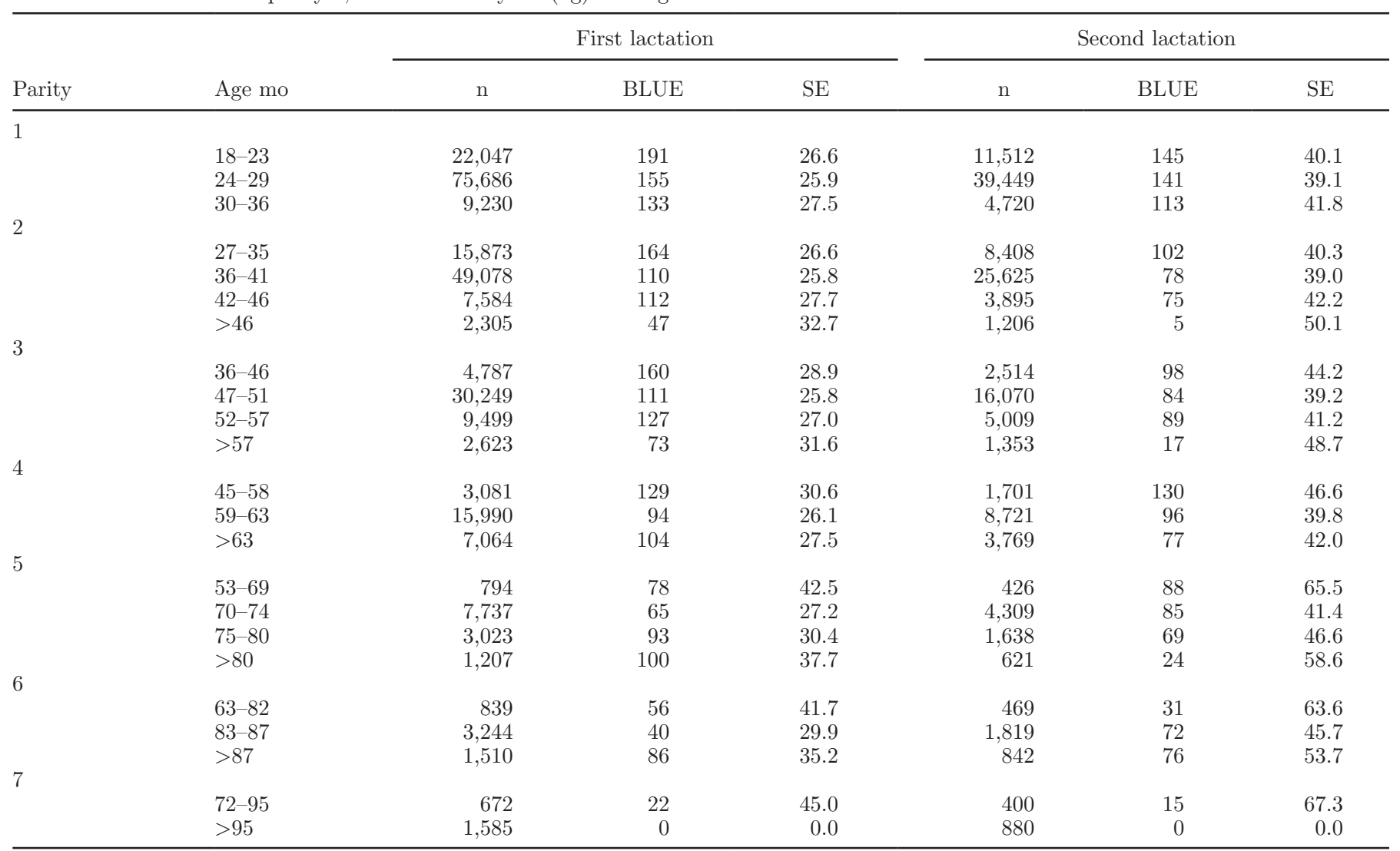

daughters in first and second lactation, and were higher overall for daughters of younger dams.

The pedigree file had a total of 726,826 animals, consisting of the 275,707 daughters with data and their pedigree (sire and dam) traced back as far as possible

\section{Statistical Analyses}

General linear model (GLM) analyses in SAS version 9.3 (SAS Institute Inc., Cary, NC) were conducted to test which explanatory variables had a significant ef- fect on 305-d milk yield in first and second lactations, respectively. Age at calving, year-month of calving, parity of dam, age of dam, and herd-year of calving had significant effects on both traits.

Two different definitions of age of dam were used: parity of dam (parity 1 to 7 ) and age of dam within parity (23 classes). Age of dam was divided into 3 or 4 classes per parity, except for parity 7 , which was divided into 2 classes because of the small number of records (Table 1). Bivariate linear animal models with 305-d milk yield in first and second lactations as ge-

Table 2. Summary statistics of data used for analyses of effect of parity of dams on 305-d milk yield in Norwegian Red cows

\begin{tabular}{lcc}
\hline Item & First lactation & Second lactation \\
\hline Cows, no. & 275,707 & 145,356 \\
Herd-year, no. & 78,592 & 57,506 \\
Dams, no. & 213,855 & 122,592 \\
Sires, no. & 1,432 & 1,258 \\
Daughters of first-parity dams, $\%$ & 38.8 & 38.3 \\
Mean 305-d milk yield, kg & 6,129 & 7,059 \\
SD 305-d milk yield, kg & 1,202 & 1,396 \\
Mean age at calving, mo & 25.4 & 37.7 \\
SD age at calving, mo & 2.6 & 3.2 \\
\hline
\end{tabular}




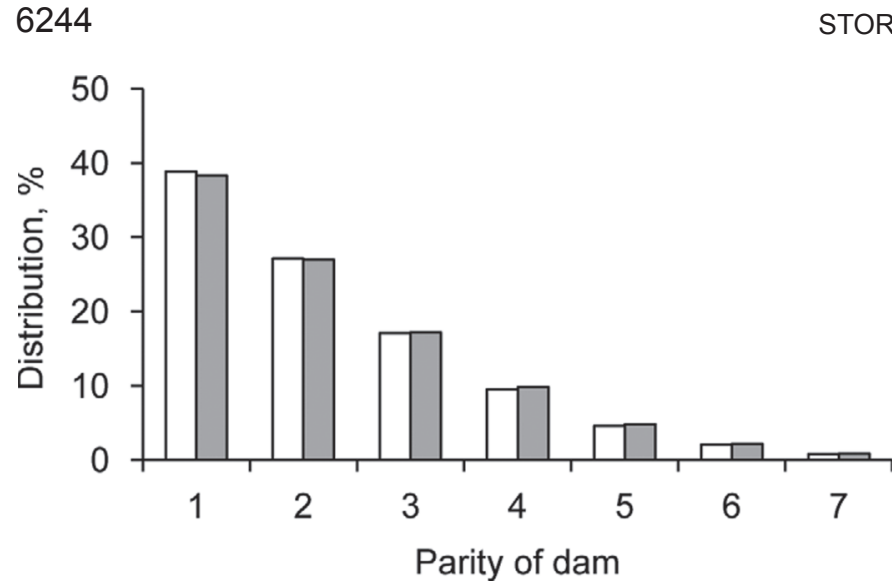

Figure 1. Distribution of parity of dam for 275,707 Norwegian Red daughters born from 2001 to 2011; white bar = first-lactation cows, gray bar $=$ second-lactation cows. netically correlated traits were fitted. By using a model with genetic effect of animal, the genetic trend in the population is taken into account. In matrix notation, the model was

$$
\mathbf{y}=\mathbf{X} \boldsymbol{\beta}+\mathbf{Z}_{h} \mathbf{h}+\mathbf{Z}_{a} \mathbf{a}+\mathbf{e},
$$

where $\mathbf{y}$ is the observed records of $305-\mathrm{d}$ milk yield in first and second lactation, respectively; $\boldsymbol{\beta}$ is the vector of systematic effects, including age at calving (19 classes in first and 34 in second), parity of dam (7 classes) or age $\times$ parity of dam (23 classes), and the effects of year $\times$ month of calving (119 classes in first lactation and 106 in second); $\mathbf{h}$ is the vector of herd-year at calving effects; $\mathbf{a}$ is the vector of genetic effect of animal (daughter); $\mathbf{e}$ is the vector of residuals; and $\mathbf{X}, \mathbf{Z}_{h}$, and $\mathbf{Z}_{a}$, are the corresponding incidence matrices.

The following (co)variance structures were assumed for random effects:

$$
\begin{gathered}
\mathbf{h} \sim \mathrm{N}(\mathbf{0}, \mathbf{H} \otimes \mathbf{I}), \mathbf{a} \sim \mathrm{N}(\mathbf{0}, \mathbf{G} \otimes \mathbf{A}), \\
\text { and } \mathbf{e} \sim \mathrm{N}(\mathbf{0}, \mathbf{R} \otimes \mathbf{I}),
\end{gathered}
$$

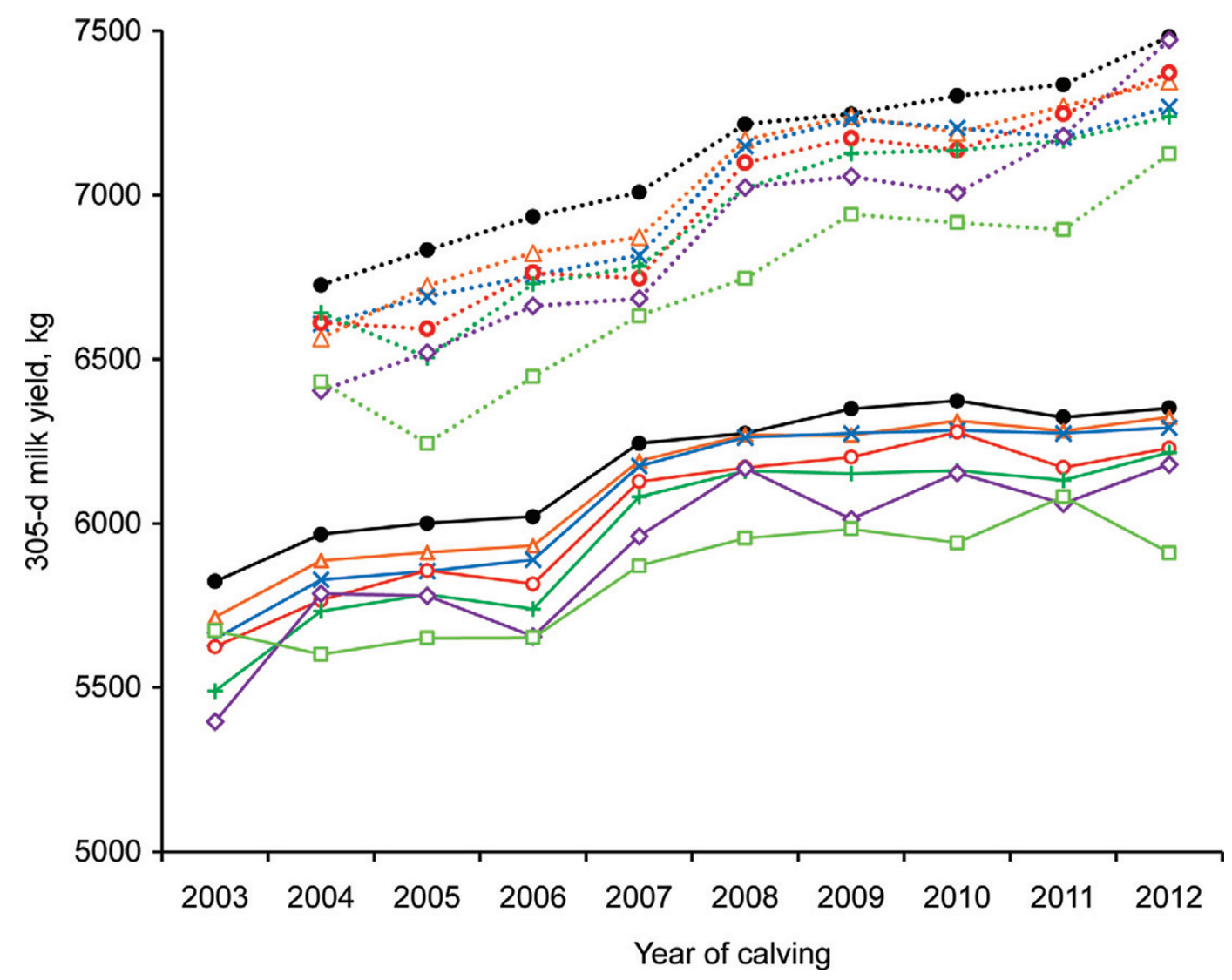

Figure 2. Phenotypic trend, average 305-d milk yield $(\mathrm{kg})$ in first- (solid lines) and second- (dotted lines) lactation daughters calving from 2003 to 2012 by parity of dams: first $=\bullet$ (black), second $=\Delta$ (orange), third $=\times$ (blue), fourth $=\bigcirc($ red $)$, fifth $=+($ dark green $)$, sixth $=\diamond$ (purple), and seventh $=\square$ (light green). Color version available in online PDF. 
Table 3. Estimated effects (BLUE = best linear unbiased estimator) with standard error of parity of dam, expressed as deviation from dams in parity 7, on 305-d milk yield $(\mathrm{kg})$ of daughters in first and second lactation

\begin{tabular}{lccccccc}
\hline & \multicolumn{3}{c}{ First lactation } & & \multicolumn{3}{c}{ Second lactation } \\
\cline { 2 - 5 } \cline { 6 - 8 } Parity & no. & BLUE & SE & & no. & BLUE & SE \\
\hline 1 & 106,963 & 149 & 22.0 & & 55,681 & 130 & 32.7 \\
2 & 74,840 & 109 & 21.7 & & 39,134 & 72 & 32.5 \\
3 & 47,158 & 107 & 21.6 & & 24,946 & 75 & 32.5 \\
4 & 26,135 & 92 & 21.8 & & 14,191 & 88 & 32.9 \\
5 & 12,761 & 67 & 22.5 & & 6,994 & 71 & 34.0 \\
6 & 5,593 & 47 & 24.3 & & 3,130 & 61 & 36.8 \\
7 & 2,257 & 0 & 0 & & 1,280 & 0 & 0 \\
\hline
\end{tabular}

where

$$
\begin{gathered}
\mathbf{H}=\left[\begin{array}{cc}
\sigma_{h y 1}^{2} & \sigma_{h y 12} \\
\sigma_{h y 12} & \sigma_{h y 2}^{2}
\end{array}\right], \\
\mathbf{G}=\left[\begin{array}{cc}
\sigma_{g 1}^{2} & \sigma_{g 12} \\
\sigma_{g 12} & \sigma_{g 2}^{2}
\end{array}\right], \\
\text { and } \mathbf{R}=\left[\begin{array}{cc}
\sigma_{e 1}^{2} & \sigma_{e 12} \\
\sigma_{e 12} & \sigma_{e 2}^{2}
\end{array}\right] .
\end{gathered}
$$

Here, $\mathbf{H}, \mathbf{G}$, and $\mathbf{R}$ were herd-year, genetic, and residual (co)variance matrices, respectively, between the 2 traits (first- and second-lactation 305-d milk yield); A was the additive genetic relationship matrix; I was an identity matrix; $\sigma_{h y 1}^{2}$ and $\sigma_{h y 2}^{2}$ are the herd-year variances of 305-d milk yield in first and second lactation, respectively, and $\sigma_{h y 12}$ is the herd-year covariance between the 2 traits; $\sigma_{g 1}^{2}$ and $\sigma_{g 2}^{2}$ are the genetic variances and $\sigma_{g 12}$ is the genetic covariance of 305-d yield in first and second lactation; $\sigma_{e 1}^{2}, \sigma_{e 2}^{2}$, and $\sigma_{e 12}$ are the residual (co)variances of 305-d yield in first and second lactation.

The DMUAI routine in the DMU software (Madsen and Jensen, 2008) was used to estimate (co)variance components and predict breeding values and solutions for fixed effects.

\section{RESULTS AND DISCUSSION}

\section{Parity of Dam}

Estimated effects of parity of dam on daughters 305$\mathrm{d}$ milk yield in first and second lactations, expressed as deviation from parity 7 , are shown in Table 3. Increasing parity number of dam had a negative effect on daughters' 305-d milk yield in first and in second lactation. Daughters of first-parity dams had 149-kg higher 305-d milk yield in their first lactation than did daughters of seventh-parity dams. In the second lactation, the difference was $130 \mathrm{~kg}$ of milk. Differences between parities 2 to 5 were not significant (because their estimates \pm standard errors overlap) for either first- or second-lactation milk yield. Second-parity daughters produced, on average, 40 and $58 \mathrm{~kg}$ less milk in first and second lactations, respectively, than did first-parity daughters, but the difference was not significant. For second-lactation daughters, we detected no significant difference in 305-d milk yield if dams were in parities 2 to 6.

To our knowledge, this effect of parity of dams has not been shown previously. Fuerst-Waltl et al. (2004) analyzed effect of age classes of dams at calving, regardless of parity, in Austrian dual-purpose Simmental, and found that the older the dam, the lower the milk yield of their daughters. The oldest dams in the present study (seventh parity) were 6 to $8 \mathrm{yr}$ old, and would correspond to age classes 3 and 4 of Fuerst-Waltl et al. (2004). The difference between first and seventh parities in the present study were 149 and $130 \mathrm{~kg}$ of milk in first and second lactations of daughters, respectively, whereas the differences between age classes 1 and 4 reported by Fuerst-Waltl et al. (2004) were 83 and 89 $\mathrm{kg}$ of ECM in first and second lactations of daughters, respectively.

It is not entirely clear what distinguishes a first-parity heifer from the same animal as a second- or higherparity cow that could explain the difference between daughters' production. One major difference, however, is the high energetic demand of lactation that has to be met by a second- or later-parity dam compared with a first-parity one. A pregnant heifer needs energy and nutrients for maintenance, for her own growth and development, and for growth and development of the fetus. Heifers are generally managed to calve at greater BCS than multiparous herdmates, which, in turn, will lead to reduced postpartum DMI (Roche et al., 2009). Moreover, Holstein-Friesian first-parity cows fail 
to regain their BCS as effectively as older cows after peak lactation, probably because they are still growing (Berry et al., 2008). During early lactation, the energy demand for milk production is normally higher than the energy supply, particularly in high-yielding individuals, hence the cow has to mobilize from body tissues (Bauman and Currie, 1980).While experiencing this period of negative energy balance, the animal should then resume estrous cyclicity and become pregnant for the second time. The unfavorable relationship between negative energy balance and fertility is well documented (Butler, 2003; Wathes et al., 2007; Lucy, 2008). During the second pregnancy, the cow again needs energy and nutrients for maintenance, her own growth, and growth and development of the fetus. Demands for growth of the fetus will be the same but, compared with the first pregnancy, maintenance demands will be higher, and demands for the cow's own growth will be lower. The single factor contributing most to the difference between a first- and second-parity cow is that the second-parity cow needs energy and nutrients for milk production during the pregnancy. Looking at the third pregnancy compared with the second pregnancy, maintenance costs will be somewhat higher, demands for the cow's own growth will still be lower, and demands for growth and development of the fetus will again be the same. But during her third lactation and pregnancy, the cow will need energy and nutrients for even higher production than during her previous lactations (Schutz et al., 1990; Banos et al., 2007). From the third parity on, the cow will be fully grown and, as long as the cow stays healthy, the differences between demands for nutrients and energy from one pregnancy to the next will vary less. This line of events may explain a major part of the effects of parity of dam in Table 3.

Over the last decade, several authors have discussed whether epigenetic effects of an adverse uterine environment in the dam might affect the fetus and subsequent performance of the offspring (Butler, 2003; Roche et al., 2009; Schoonmaker and Eastridge, 2013). A wellfunctioning placenta is important for an adequate supply of nutrients to and removal of heat and waste from the fetus. However, the uterine environment would probably have to be extremely adverse to seriously affect fetal growth. This is clearly illustrated in the study of effects of extreme malnutrition on the offspring of women who were pregnant during the Dutch famine in the winter of 1944 to 1945 (see, for example, Roseboom et al., 2001). In that study, effects on health in later life were dependent on the timing of malnutrition during gestation but no effects on, for example, birth size of the baby were noted. In today's conventional dairy production, offspring will never have experienced remotely comparable adverse uterine environments.
On the other hand, it is not clear whether the results from human underfeeding are applicable to dairy cows. Thus, the potential effects of negative energy balance or underfeeding during key periods of embryo and fetal development cannot be excluded. In any case, both occasional overfeeding and underfeeding due to different management practices were taken into account by including the herd-year effect in the model.

\section{Age Within Parity of Dam}

Table 1 shows the estimated effects of age $\times$ parity of dam, expressed as deviation from dams older than 95 mo in parity 7 on 305-d milk yield of daughters in first and second lactation. The effect of age $\times$ parity of dam was highest for the youngest dams in all parities except for first-lactation daughters of fifth-parity dams and daughters of sixth-parity dams. The difference in 305-d milk yield of daughters from young and old dams (it should be noted that the terms "young" and "old" refer to a normal range of age at calving) within parity were significantly different for first-lactation daughters of first-, second-, and third-parity dams. Daughters of young dams produced, on average, 58,117 , and $87 \mathrm{~kg}$ more milk in first lactation than did daughters of old first-, second-, and third-parity dams, respectively. This is consistent with the findings of Banos et al. (2007), showing that daughters of young first-parity Holstein dams produced $1.18 \mathrm{~kg}$ more milk on the third test-day than did daughters of older first-parity dams. Daughters of young second-parity dams also produced significantly more milk in their second lactation than did daughters of old second-parity dams. The milk yield of daughters from young and old dams in parities 4, 5, 6, and 7 were not significantly different.

The differences in milk yield between daughters of young and old first-parity dams could, to some extent, be a function of age and size of the animal. Herd management will affect age at first calving (AFC). Some farmers may prefer to have heifers with a high AFC, because older heifers are expected to produce more milk than young heifers. The effect of AFC on subsequent milk yield has been studied by several authors (e.g., Van Amburgh et al., 1998; Ettema and Santos, 2004) and is confirmed in our data (Figure 3). However, the association between AFC and milk yield could also be ascribed to BW at calving, because older heifers usually have a higher BW at calving than young heifers (Van Amburgh et al., 1998). Ettema and Santos (2004) showed that milk yield did not differ between younger and older Holstein heifers until $50 \mathrm{~d}$ in milk; thereafter, the older heifers increased their yield. Those authors further discussed whether a low BW at first calving could be an indirect disadvantage for the subsequent 


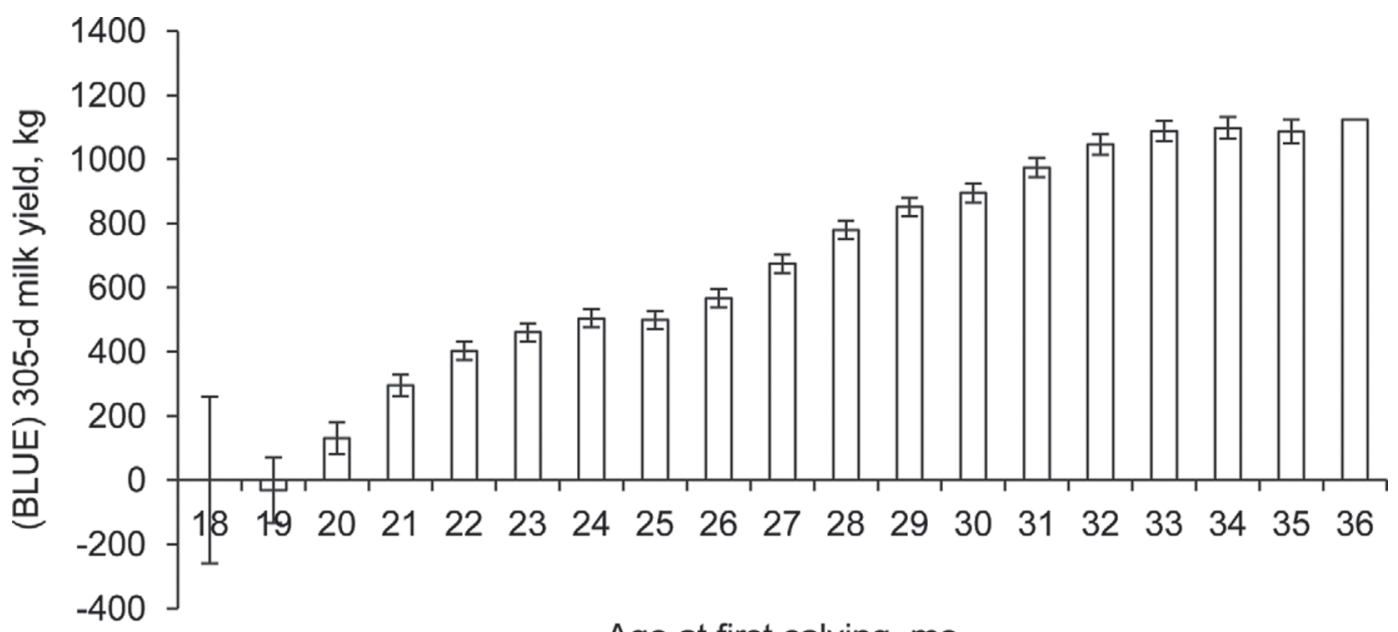

Age at first calving, mo

Figure 3. Effect of age of daughters at first calving on their 305-d milk yield expressed as deviation from 18 mo. (BLUE = best linear unbiased estimator). Error bars indicate standard error.

milk yield of the cow. First, heifers with low BW at calving are known to have a higher risk of dystocia, and dystocia is often associated with decreased milk yield in the first lactation (Berry et al., 2007; Eaglen et al., 2011). Second, small heifers may have a lower DMI than their potential because of the high competition for feed with larger herdmates (Ettema and Santos, 2004).

Milk yield of different age classes of first- and secondparity dams should be distributed similarly to the milk yield of the daughters in first and second lactation, as presented in Figures 3 and 4, respectively. This is also supported by the findings of Ettema and Santos (2004). Thus, young first-parity dams will produce less milk than older first-parity dams. This effect of age $\times$ parity of dam would also be expected to continue into the subsequent parities of the dam. As parity number increases, the number of animals in each group will inevitably decrease because an increasing number of animals are culled. Thus, the effect of age $\times$ parity of dam will be less evident toward parity 7 .

The reasons for the effect of age $\times$ parity of dam are not known. But if age and BW at first calving are major factors, a heifer management system should favor heifers to calve large, lean, and young; no conflict necessarily exists between being large and lean on one side and young on the other. Being large would also mean that the heifers are closer to their mature BW at first calving. Consequently, they would allocate less

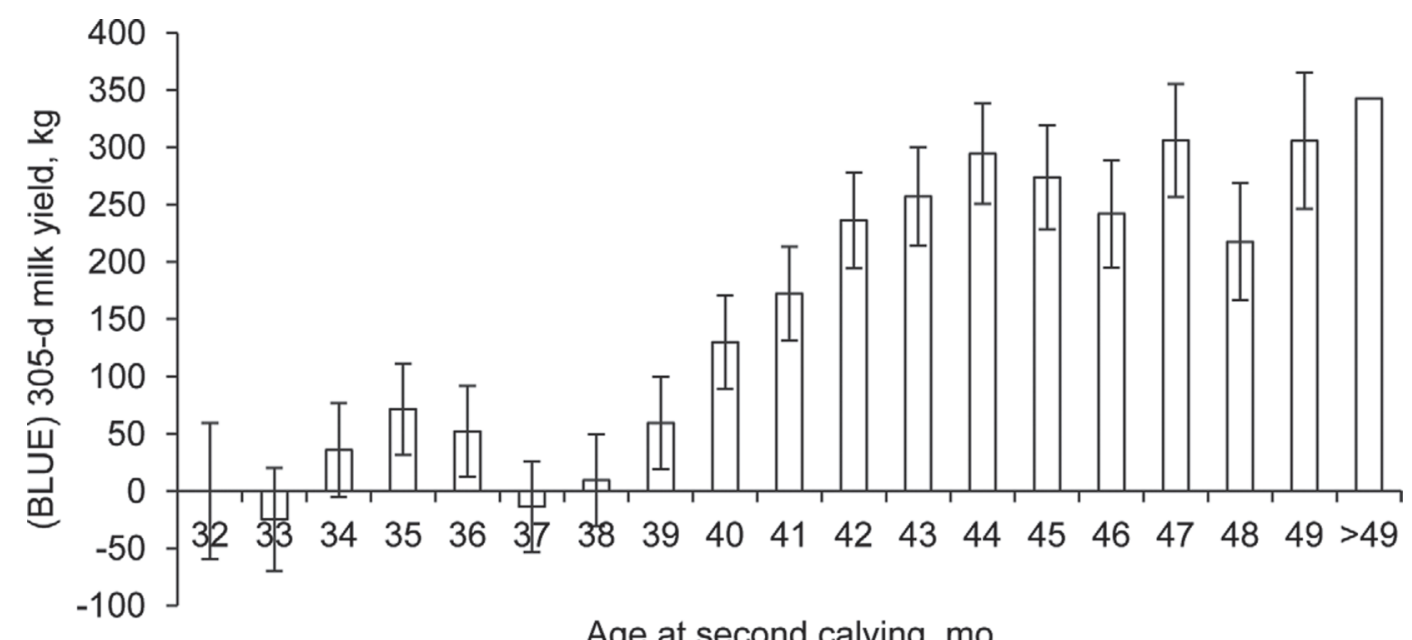

Figure 4. Effect of age of daughters at second calving on their 305-d milk yield expressed as deviation from 32 mo. (BLUE = best linear unbiased estimator). Error bars indicate standard error. 
energy to their own growth and more to milk production in their first lactation.

\section{Other Effects}

Age at first calving affects 305-d milk yield in first lactation, as shown in Figure 3. Young first-lactation cows produce less milk than older first-lactation cows, but the effect of age levels off at around 33 mo of age. This is consistent with results shown by others (Lin et al., 1986; Van Amburgh et al., 1998; Ettema and Santos, 2004). A similar trend for second-lactation cows is shown in Figure 4, with increasing milk yield from 38 mo of age at calving. The effect of AFC on 305-d milk yield is much greater than the effect of parity and age of dam. As mentioned, low AFC is often associated with lower BW at calving, which could be the reason for the lower milk yield.

Estimated effects of year $\times$ month of calving showed that 305-d milk yield has increased over time and that seasonal variations exist (results not shown); cows calving in autumn tend to produce more milk than cows calving in early spring and summer. During the summer, most Norwegian cows stay on pasture. Because of variable weather conditions and roughage quality during summer, feeding is more stable during winter.

\section{Heritability and Correlations}

In both models, estimated heritabilities of 305-d milk yield of daughters were 0.46 and 0.44 in the first and second lactations, respectively. Estimated heritabilities for 305-d milk yield in the present study were higher than the heritability of 0.277 used in routine genetic evaluations for Norwegian Red (Geno Breeding and AI Association, 2014). This is probably because only cows that had completed $305 \mathrm{~d}$ of lactation were used in the present study.

Estimated (co)variance components were similar for both models. The estimated genetic correlation between 305-d yield in first and second lactation was 0.92 (SE 0.005). This estimate is consistent with the genetic correlation of 0.90 reported by Carlén et al. (2004) for Swedish Holstein. The estimated herd-year and residual correlations were 0.78 (SE 0.006) and 0.19 (SE 0.009), respectively. Estimated correlations for the model with age $\times$ parity of dam were identical, except for estimated residual correlation of 0.18 (SE 0.009).

\section{Age at Calving}

Results from the present study illustrate a conflict of interest in whether the dam or the daughter should be young or old at first calving. If the dam is young at first calving, her daughter is expected to produce more milk than a daughter of an older first-parity dam. On the other hand, our results, as well as those of other studies (Van Amburgh et al., 1998; Ettema and Santos, 2004), show that young heifers produce less milk than older heifers. Thus, both age and parity of dam should be included in future models aiming to detect differences in milk yield.

\section{CONCLUSIONS}

Extensive use of heifers as dams would have a systematic effect because daughters of heifers produced more milk than did daughters of older dams. Within parity, young dams gave higher-producing daughters than did older dams.

\section{ACKNOWLEDGMENTS}

The authors acknowledge the Norwegian Dairy Herd Recording System (Ås, Norway) for access to data, and the Research Council of Norway (Oslo) for funding (project number 199448).

\section{REFERENCES}

Banos, G., S. Brotherstone, and M. P. Coffey. 2007. Prenatal maternal effects on body condition score, female fertility, and milk yield of dairy cows. J. Dairy Sci. 90:3490-3499. http://dx.doi. org/10.3168/jds.2006-809.

Bauman, D. E., and W. B. Currie. 1980. Partitioning of nutrients during pregnancy and lactation: A review of mechanisms involving homeostasis and homeorhesis. J. Dairy Sci. 63:1514-1529. http:// dx.doi.org/10.3168/jds.S0022-0302(80)83111-0.

Berry, D. P., J. M. Lee, K. A. Macdonald, and J. R. Roche. 2007. Body condition score and body weight effects on dystocia and stillbirths and consequent effects on postcalving performance. J. Dairy Sci. 90:4201-4211. http://dx.doi.org/10.3168/jds.2007-0023.

Berry, D. P., P. Lonergan, S. T. Butler, A. R. Cromie, T. Fair, F. Mossa, and A. C. O. Evans. 2008. Negative influence of high maternal milk production before and after conception on offspring survival and milk production in dairy cattle. J. Dairy Sci. 91:329-337. http://dx.doi.org/10.3168/jds.2007-0438.

Butler, W. R. 2003. Energy balance relationships with follicular development, ovulation and fertility in postpartum dairy cows. Livest. Prod. Sci. 83:211-218. http://dx.doi.org/10.1016/S03016226(03)00112-X.

Carlén, E., E. Strandberg, and A. Roth. 2004. Genetic parameters for clinical mastitis, somatic cell score, and production in the first three lactations of Swedish Holstein cows. J. Dairy Sci. 87:30623070. http://dx.doi.org/10.3168/jds.S0022-0302(04)73439-6.

Eaglen, S. A. E., M. P. Coffey, J. A. Woolliams, R. Mrode, and E. Wall. 2011. Phenotypic effects of calving ease on the subsequent fertility and milk production of dam and calf in UK Holstein-Friesian heifers. J. Dairy Sci. 94:5413-5423. http://dx.doi.org/10.3168/ jds.2010-4040.

Ettema, J. F., and J. E. P. Santos. 2004. Impact of age at calving on lactation, reproduction, health, and income in first-parity Holsteins on commercial farms. J. Dairy Sci. 87:2730-2742. http:// dx.doi.org/10.3168/jds.S0022-0302(04)73400-1.

Fuerst-Waltl, B., A. Reichl, C. Fuerst, R. Baumung, and J. Sölkner. 2004. Effect of maternal age on milk production traits, fertility, 
and longevity in cattle. J. Dairy Sci. 87:2293-2298. http://dx.doi. org/10.3168/jds.S0022-0302(04)70050-8.

Geno Breeding and AI Association. 2014. Egenskapene i avlsarbeidet. Accessed Feb. 12, 2014. http://www.geno.no/Start/Avl/Avlsmal/ Egenskapene-i-avlsmalet $/$ id $=317$ \&epslanguage $=$ no. $\quad($ In Norwegian.)

Lin, C. Y., A. J. McAllister, T. R. Batra, A. J. Lee, G. L. Roy, J. A. Vesely, J. M. Wauthy, and K. A. Winter. 1986. Production and reproduction of early and late bred dairy heifers. J. Dairy Sci. 69:760-768. http://dx.doi.org/10.3168/jds.S0022-0302(86)804659.

Lucy, M. C. 2008. Functional differences in the growth hormone and insulin-like growth factor axis in cattle and pigs: Implications for post-partum nutrition and reproduction. Reprod. Domest. Anim. 43(Suppl. 2):31-39. http://dx.doi.org/10.1111/j.14390531.2008.01140.x.

Madsen, P., and J. Jensen. 2008. A User's Guide to DMU: A Package for Analysing Multivariate Mixed Models. Version 6, release 4.7. Department of Genetics and Biotechnology, Faculty of Agricultural Sciences (DJF), University of Aarhus, Research Centre Foulum, Tjele, Denmark.

Roche, J. R., N. C. Friggens, J. K. Kay, M. W. Fisher, K. J. Stafford, and D. P. Berry. 2009. Invited review: Body condition score and its association with dairy cow productivity, health, and welfare. J. Dairy Sci. 92:5769-5801. http://dx.doi.org/10.3168/jds.20092431.
Roseboom, T. J., J. H. P. van der Meulen, A. C. J. Ravelli, C. Osmond, D. J. P. Barker, and O. P. Bleker. 2001. Effects of prenatal exposure to the Dutch famine on adult disease in later life: An overview. Mol. Cell. Endocrinol. 185:93-98. http://dx.doi. org/10.1016/S0303-7207(01)00721-3.

Schoonmaker, J., and M. Eastridge. 2013. Effect of maternal nutrition on calf health and growth. Pages 63-80 in Proc. 22nd Tri-State Dairy Nutr. Conf., Fort Wayne, IN. Michigan State University, East Lansing.

Schutz, M. M., L. B. Hansen, G. R. Steuernagel, and A. L. Kuck. 1990. Variation of milk, fat, protein, and somatic cells for dairy cattle. J. Dairy Sci. 73:484-493. http://dx.doi.org/10.3168/jds. S0022-0302(90)78696-1.

Van Amburgh, M. E., D. M. Galton, D. E. Bauman, R. W. Everett, D. G. Fox, L. E. Chase, and H. N. Erb. 1998. Effects of three prepubertal body growth rates on performance of Holstein heifers during first lactation. J. Dairy Sci. 81:527-538. http://dx.doi. org/10.3168/jds.S0022-0302(98)75604-8.

Wathes, D. C., M. Fenwick, Z. Cheng, N. Bourne, S. Llewellyn, D. G. Morris, D. Kenny, J. Murphy, and R. Fitzpatrick. 2007. Influence of negative energy balance on cyclicity and fertility in the high producing dairy cow. Theriogenology 68(Suppl. 1):S232-S241. http://dx.doi.org/10.1016/j.theriogenology.2007.04.006. 